\title{
Song mimicry and species associations of west African indigobirds Vidua with Quail-finch Ortygospiza atricollis, Goldbreast Amandava subflava and Brown Twinspot Clytospiza monteiri
}

\author{
ROBERT B. PAYNE \& LAURA L. PAYNE \\ Museum of Zoology and Department of Biology, University of Michigan, Ann Arbor, Michigan 48109, USA
}

\begin{abstract}
The brood-parasitic indigobirds Vidua spp. mimic the songs of their foster species, which for many species of indigobirds are Lagonosticta firefinches. We report additional associations of indigobirds with estrildid finches in west Africa. Quail-finch Indigobirds Vidua nigeriae in northern Cameroon mimic the songs of Quail-finch Ortygospiza atricollis. Goldbreast Indigobirds Vidua raricola in Cameroon and Sierra Leone mimic the songs of Goldbreast Amandava subflava. Both indigobirds are distinct in male breeding plumage from other indigobirds. Also, a population of blue indigobirds Vidua sp. in Cameroon mimics the songs of Brown Twinspot Clytospiza monteiri. They are similar in colour and size to blue indigobirds associated with Dark Firefinch $L$. rubricata and Black-bellied Firefinch $L$. rara. Mouth patterns of fledged young Quail-finch Indigobirds and Goldbreast Indigobirds resemble those of their song-model and presumed foster species, but the mouth pattern of a fledged young associated with the Brown Twinspot mimic was not distinct from the mouth of young Black-bellied Firefinch. The field observations show associations of certain species of indigobirds with finches other than the firefinches. The results are consistent with mitochondrial DNA estimates of greater genetic similarity among indigobirds than among their foster species. The field observations support the hypothesis of evolutionary associations of the brood parasite and foster species by colonization with switching from one foster to another rather than by cospeciation.
\end{abstract}

The African indigobirds Vidua spp. are brood parasitic finches that are often associated with the estrildid firefinches Lagonosticta spp. (Nicolai 1964, Payne 1968, 1973, 1976. $1982,1985 a, b)$. Each indigobird, like most other kinds of Vidua, mimics the songs of its foster species. The young mimic the mouth pattern of the young nestlings of their foster species. Their associations with the foster species led to a suggestion that the Vidua cospeciated with them, diverging at the same time as their foster species (Nicolai 1967. $1969,1973,1977)$. However, other explanations of the origin of the associations are possible and should be examined as alternative hypotheses. In contrast to a hypothesis of cospeciation, we find support for a hypothesis of association by colonization when a brood parasite switches from one foster species to another (Payne 1973, Klein et al. 1993. Payne et al. 1993).

Recent field work has revealed that some populations of indigobirds mimic the songs of finches other than the $L a$ gonosticta firefinches. Like the firefinch mimics, each male mimics the songs of a single species of estrildid finch. In Malawi, Zambia and Zimbabwe, Peters' Twinspot Indigobirds Vidua codringtoni, which mimic the songs of Peters' Twinspot Hypargos niveoguttatus (Payne et al. 1992, 1993), are distinct from other indigobirds in plumage, bill and foot colours in both males and females. The females visit the singing males at their mating sites, and the birds behave as a distinct species. Here we describe three additional associations of indigobirds and foster species. Two of these indigobirds were described previously as species, but their associations with the foster species were unknown (Quailfinch Indigobirds Vidua nigeriae) or were described from mixed samples of song (Goldbreast Indigobirds $V$. raricola). The first mimics the songs of Quail-finch Ortygospiza atricollis and the second mimics the songs of Goldbreast Amandava subflava. Also, we describe a population of Cameroon Indigobirds $V$. camerunensis with the songs of Brown Twinspot Clytospiza monteiri. Together with the association of $V$. codringtoni with Peters' Twinspot, we now know four kinds of indigobirds that are associated with foster species other than the firefinches.

\section{STUDY SITES, MATERIAL AND METHODS}

Field work was carried out in 1979, 1980 and 1992 in northern Cameroon, with additional observations in Nigeria, Ghana and Sierra Leone (reported in part in Payne 1973, 1976, 1982, 1985a, Payne \& Groschupf 1984). Field localities in Cameroon were Garoua $\left(09^{\circ} 17^{\prime} \mathrm{N}, 13^{\circ} 26^{\prime} \mathrm{E}, 180 \mathrm{~m}\right.$ a.s.l.), Tchéboa $\left(09^{\circ} 02^{\prime} \mathrm{N}, 1^{\circ} 06^{\prime} \mathrm{E}, 200 \mathrm{~m}\right)$, Ngaoundére $\left(07^{\circ} 22^{\prime} \mathrm{N}\right.$, 


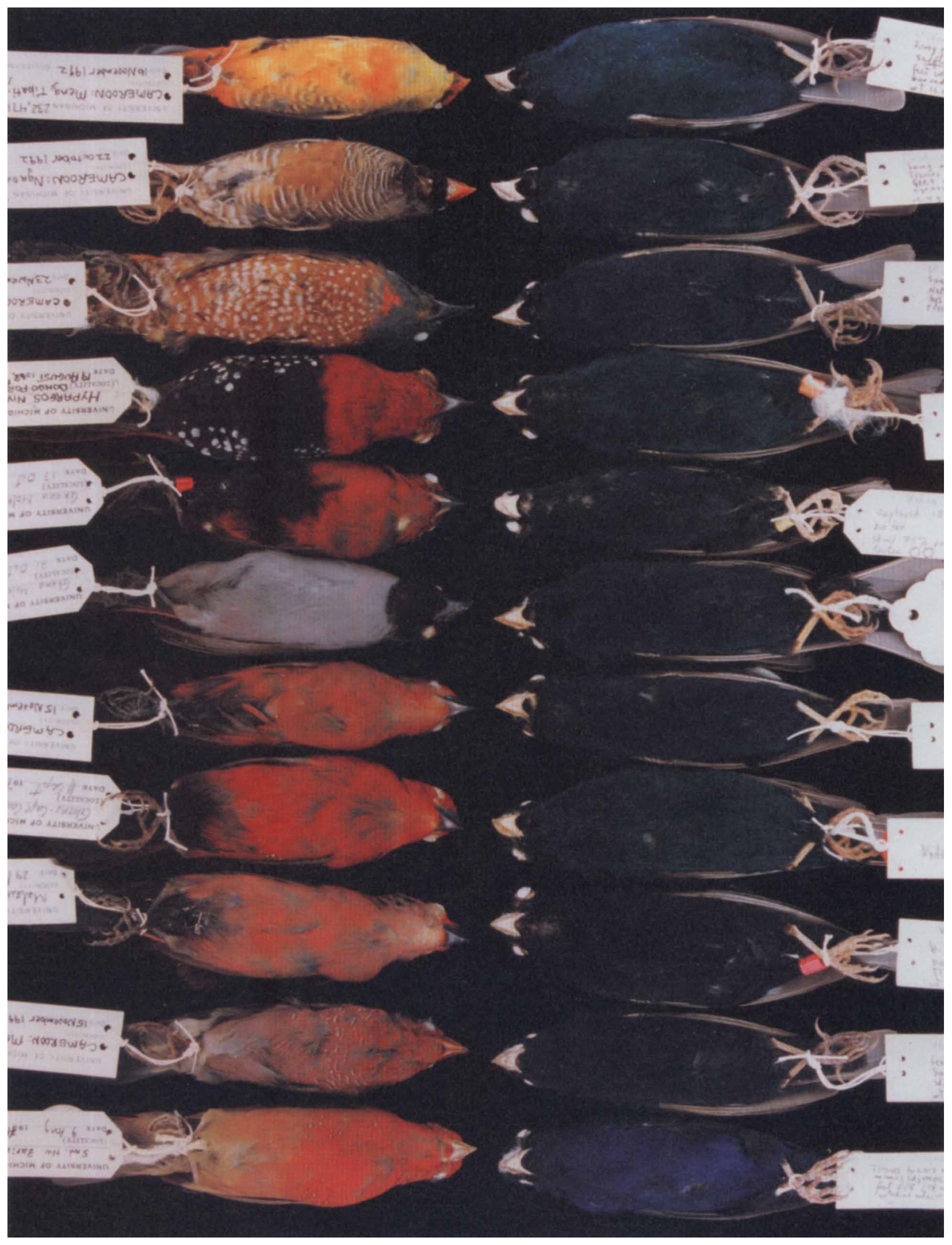


$\left.13^{\circ} 34^{\prime} \mathrm{E}, 1090 \mathrm{~m}\right)$, Wakwa $\left(07^{\circ} 14^{\prime} \mathrm{N}, 13^{\circ} 35^{\prime} \mathrm{E}, 1150 \mathrm{~m}\right)$, Meng $\left(06^{\circ} 31^{\prime} \mathrm{N}, 12^{\circ} 36^{\prime} \mathrm{E}, 1200 \mathrm{~m}\right)$, Tibati $\left(06^{\circ} 28^{\prime} \mathrm{N}, 12^{\circ} 38^{\prime} \mathrm{E}, 1200\right.$ $\mathrm{m})$ and Banyo $\left(06^{\circ} 45^{\prime} \mathrm{N}, 11^{\circ} 50^{\prime} \mathrm{E}, 1060 \mathrm{~m}\right)$.

Singing male Vidua were tape recorded with a Uher 4000 series tape recorder (at 4.5 or $9.7 \mathrm{~mm} / \mathrm{s}$ ) and $45-\mathrm{cm}$ parabolic reflector in 1979 and 1980 and a Sony TC-D5M tape recorder and 33-cm parabolic reflector in 1992. Females were netted as they visited the singing males at their call-sites, where they mate. Females ovulate with the yolk passing into the oviduct at this time (Payne 1973, 1977), and only those females at the male sites were identified with certainty as associated with the male.

Specimens were compared with museum series, including type specimens (Payne 1982). Colour comparisons of the live birds were made with the Methuen guide (Kornerup \& Wanscher 1967), and plumages were compared in sunlight and under a Macbeth Super Skylight.

Recordings of the foster species were from our field work and other field workers and from birds in captivity. Audiospectrograms were examined on a VGA screen with a Kay Elemetrics DSP Digital Sound Processor from 0-16 kHz using a 256-points per s (234 Hz) filter, with a band-pass filter to remove noise below $1.5 \mathrm{kHz}$, and were printed with a Mitsubishi P61U printer. We determined the associations of indigobirds and their song mimics from the similarities between audiospectrograms as well as by recognizing the shared patterns by ear and by excluding the calls and songs of other kinds of estrildid finches that live in the same areas.

Birds observed in captivity were obtained from importers, and their origins were unknown; the captives included two mimics of Black-bellied Firefinch Lagonosticta rara and one of Bar-breasted Firefinch L. rufopicta. Male indigobirds were tape recorded, and their song mimicry was determined by comparison with songs of foster species. Quail-finch were identified by comparisons with museum series as $O$. a muelleri from east to south-central Africa and $O$. a. ansorgei from the southern Upper Guinea region of west Africa. Captive Goldbreast were A. s. subflava of west and central Africa. Observations of calls and mouth patterns of young finches include nestlings and fledglings reared in captivity.

\section{Quail-finch and Quail-finch Indigobirds}

Quail-finch live in grassy areas and marshes from west to east and southern Africa. They are among the most terrestrial of estrildid finches. They feed on small grass seeds on the ground. They nest on the ground, often at the base of a tuft of grass, at the end of the rains or floods when waters recede. Bates (in Bannerman 1949) found birds on the Niger River inundation zone in Mali breeding in January "when the tussock-covered flats first become dry . . . and the grass . . . bears seed. . . " They are secretive and are better known in avicultural studies than in the field (Immelmann et al. 1965, Kunkel 1966, Goodwin 1982, Nuttall 1992).

We observed Quail-finch in Cameroon on the Benue River floodplains at Garoua in 1979, 1980 and 1992 and in a grassy marsh at Ngaoundére in 1992. They were common in pairs flying overhead and feeding on the ground. The dull green Quail-finch Indigobirds at Garoua mimicked only the songs and calls of the Quail-finch. We found no nests or broods of Quail-finch or fledged young indigobirds in October and November 1992. Fledged Quail-finch and juvenile indigobirds were seen in early January 1979. The finches apparently breed after the lands have drained of most standing water. At Garoua the last rains fell in mid-October in 1992.

\section{Calls and songs of Quail-finch}

The social contact call is a short, harsh klek (Fig. 1a and b) that rises quickly to $3-4 \mathrm{kHz}$ and lasts for about $0.07-0.1$ s. It is given by pairs feeding out of sight of each other and parents and young calling back and forth. A fledgling separated from its parents gave a harsh version (Fig. 1b). The klek matches the contact call of Güttinger \& Nicolai (1975) and appears to be the contact call described by Immelmann et al. (1965). Variants are given as excitement or alarm calls. Juveniles with conspicuous gape papillae in a family group gave a harsher call (Fig. 1c) that is perhaps a short klek. Serle (1938) described the flight call as a plaintive seep and Maclean (1985) as tink, which corresponds to the flight calls of Quail-finch at Garoua (Fig. 1d).

Song is a loud, harsh, staccato pattern with irregularly alternating notes described as like a wind clapper, a "click clack cloik ..." (Goodwin 1982) and a "rapid rattling rambling", illustrated in audiospectrogram and labelled by Maclean (1985) as klik klak kloik klik kluk klek. Songs of the west African Quail-finch O. a. ansorgei and O. a. atricollis (the form that we collected at Garoua and Ngaoundére and the form in Chad, Fig. 1i; Traylor 1963) are similar to each other and to the "klik klak kloik" songs of another subspecies in east and southern Africa (Fig. 1h and i). Male Quail-finch also give a soft sexual song or nest song ("burbling" of Nuttall

$\leftarrow$

Plate 1. Foster species and male indigobirds that mimicked their songs. Left, top to bottom: Goldbreast Amandava subflava, Quail-finch Ortygospiza atricollis, Brown Twinspot Clytospiza monteiri, Peters' Twinspot Hypargos niveoguttatus, Black-bellied Firefinch Lagonosticta rara, Black-faced Firefinch L. larvata nigricollis, Dark/Blue-billed Firefinch L. rubricata (Cameroon), L. rubricata (Ghana), Jameson's Firefinch L. rhodopareia, Bar-breasted Firefinch L. rufopicta, Red-billed Firefinch $L$. senegala. Right, top to bottom: Vidua raricola UMMZ 232484, Meng, Cameroon; V. nigeriae UMMZ 232502, Garoua, Cameroon; V. camerunensis UMMZ 232488, Meng, Cameroon; $V$. codringtoni UMMZ 231312, Premier Estate, Zimbabwe; $V$. camerunensis UMMZ 220766, Mole National Park, Ghana; $V$. larvaticola UMMZ 216995, Zaria, Nigeria; $V$. camerunensis UMMZ 203997, Banyo, Cameroon; V. maryae (holotype) UMMZ 216982, Panshanu Pass, Nigeria; V. purpurascens 231328, Lengwe National Park, Malawi; V. wilsoni UMMZ 232512, Ngaoundere, Cameroon; V. chalybeata UMMZ 232517, Garoua, Cameroon. 
Ortygospiza atricollis, Quail-finch

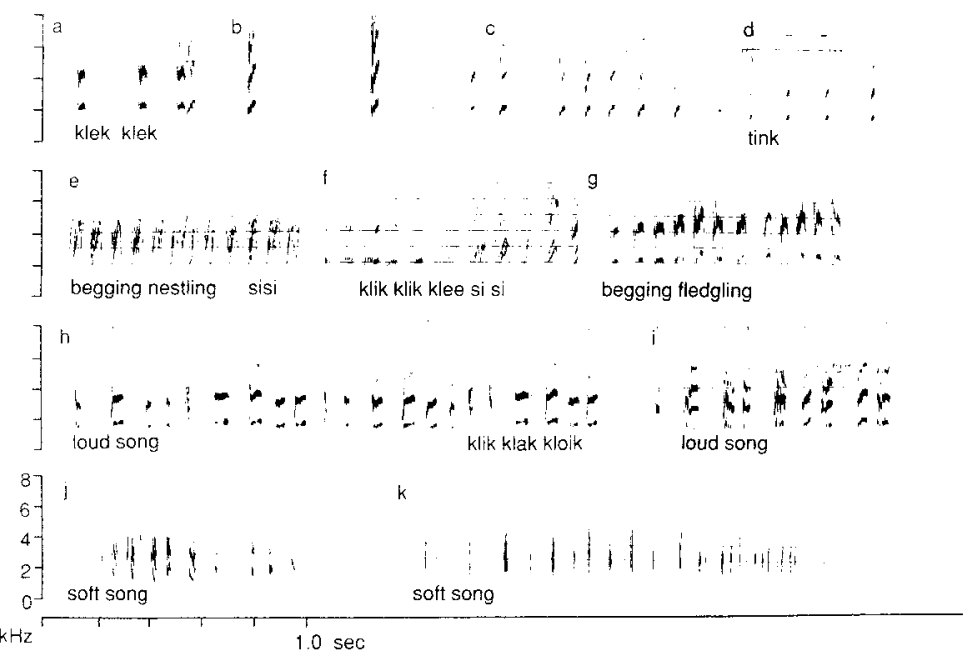

Figure 1. Songs and calls of Quail-finch. (a) Contact call $k$ lek by adult and shorter version call by its fledged young; (b) Intense klek of fledgling; (c) Klek calls given by fledgling in a family group feeding together before they flew into mist net; (d) Tink flight call by adult male flying overhead; (e) Sisisi begging calls of 12day-old nestlings; (f) Begging sequence klik-klik ... klee ... si-si of a begging 15-day-old nestling (klee as adult approaches with food): (g) Klek klik begging fledgling 2 days out of nest; (h, i) "Klik klak kloik" loud songs; ( $j, k$ ) Soft songs. ( $a, b, e-g)$ Recorded from captive $O$. a. muelleri in aviary; (c) Ngaoundére, Cameroon, 22 October 1992; (d) Garoua, Cameroon. 7 November 1992; (h, i) Adult male $O$. $a$. ansorgei in captivity; (i) O. atricollis at Moundou, Chad (J. Brunel, courtesy of C. Chappuis); (k) Adult male O. a. muelleri in captivity.

Vidua nigeriae, Quail-finch Indigobird
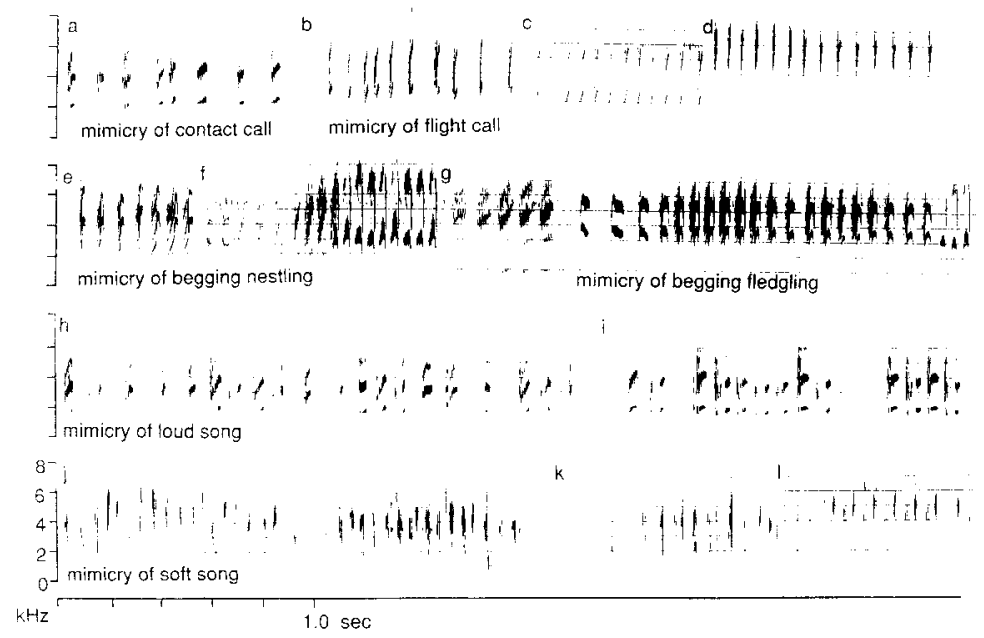

Figure 2. Mimicry songs of Quail-finch by the Quailfinch Indigobird (compare with Fig. 1). (a) Klek contact call of Quail-finch; (b-d) Tink flight calls; (e) Sisi of begging nestlings: (f) Klik-klik . . klee . . sisi of begging older nestlings; (g) Klik and klek kloik of fledgling Quail-finch; (h, i) Loud "klik klak kloik" songs; (j-l) Soft sexual songs. (a, b, e, h, j) RBP 6421, recorded at Garoua, Cameroon, 6 January 1979: (c) RBP A170. Garoua, 28 October 1992; (d, f. g, l) Colour-ringed male. Garoua, 4 November 1992; (i) Male no. 5, Garoua. 24 October 1980; (k) Male no. 4, Garoua, 24 October 1980.

1992) which is $15 \mathrm{~dB}$ lower amplitude than loud song and consists of irregularly repeated, downslurred notes of short $(<0.05 \mathrm{~s})$ duration. Like the loud songs, they have a complex harmonic structure (Fig. $1 j$ and k). Soft songs were given by a captive male $O$. a ansorgei when he was with a female. Similar songs were given by a paired captive male $O$. $a$. muelleri with his mate a few days before they nested: as in the male ansorgei, his throat vibrated with these intensely delivered songs. In the Quail-finch, the song notes klik, klek, kloik ... are variants of two frequency bands that are firstorder harmonics. A buzzy sound is associated with zigzag flag-like outlines on the audiospectrograms. The notes vary in frequency within a song. In a klek song, the notes also differ in duration and are often in triads of short, mid- and long duration (12-60 msec) (Fig. $1 \mathrm{~h}$ and i).
Begging calls of our captive young Quail-finch were audible from the day of hatching; Schifter (1963) also heard begging calls at that age. By 12 days after hatching, the young begged with a series of louder calls sisi that rose in pitch and are S-shaped on audiospectrograms (Fig. le), like the calls of young Red-billed Firefinch Lagonosticta senegala (Payne 1973). In 15-day nestlings (Fig. 1f) and fledglings, we recorded low-pitched begging calls as the parent foraged a few metres distant, then the calls shifted into higher-pitched elements as the parent approached the young and fed them. Another loud call was a series of inverted V-or U-shaped notes (Fig. 1g) like klek and klik. Juveniles gave buzzy calls with two bands of amplitude-modulated sound that trace a zigzag on audiospectrograms (Fig. 1c. d and g) and develop from a regularly repeated sequence to the irregular staccato 
of the adults (Fig. 1h and i). By 5 weeks after fledging, our Quail-finch gave loud adult staccato songs which had the klek contact calls.

\section{Vocal mimicry by Quail-finch Indigobirds}

Indigobirds with dull green plumage, pale wings and light purplish feet at Garoua gave a series of songs while perched on a call-site. Some songs were local to the population of indigobirds, while others resembled the calls and songs of Quail-finch (Fig. 2). The indigobirds mimicked the contact calls, flight calls, nestling and begging calls and the loud and soft songs of Quail-finch (compare Fig. 2 with Fig. 1). The indigobirds were tape recorded not only in 1992 but also in 1979 and 1980, but their mimetic songs were not identified then and they were not mentioned in Payne (1982). Other estrildid finches at Garoua were Red-billed Firefinch, Barbreasted Firefinch, Black-faced Firefinch L. Iarvata, Redcheeked Cordon Bleu Uraeginthus bengalus, Orange-cheeked Waxbill Estrilda melpoda, Black-rumped Waxbill E. troglodytes, Cut-throat Amadina fasciata, Bronze Mannikin Spermestes cucullatus and African Silverbill Lonchura cantans, but none had calls and songs like the dull green indigobirds. Village Indigobirds Vidua chalybeata, with glossy blue plumage, black wings and tail and orange feet, mimicked the songs of Red-billed Firefinch, and Black-faced Firefinch Indigobirds $V$. larvaticola, with blue plumage, brown wings and tail and pale purplish feet, mimicked the songs of Blackfaced Firefinch.

\section{Mouth patterns of young Quail-finch and indigobirds}

Three juvenile Quail-finch from a family group were captured and photographed at Ngaoundére on 22 October 1992. and nestlings and fledglings from five aviary broods also were photographed. The young had a pinkish-white palate with six black spots and a gape with two pale blue papillae on each side of the upper mandible and one on the lower, each bordered by black, with the corner of the gape swollen and grey. When the bill was closed, the lower papilla was opposite the black area between the two upper papillae, and the pattern of pale papillae and black areas formed a small checkerboard. The captive young retained the papillae for 3 weeks and the black palate spots for 3 months after fledging. The mouth pattern was described also by Serle (1938), Chapin (1954), van Someren (1956), Schifter (1963), Kunkel (1966) and Nuttall (1992).

Two juvenile indigobirds (UMMZ 202403, 203994) were netted and photographed at Garoua in 1979 and 1980 near a call-site of Quail-finch Indigobirds and appear to be juveniles of this form. The gape had pale grey papillae with a black base, one on the upper mandible and one on the lower, and the base of the gape was swollen and grey. Younger birds may have two papillae rather than one on the upper mandible, and the juveniles may change colour from the nestlings. The gape patterns had regressed, and the January bird had begun postjuvenal moult. Both birds had a pale pink mouth lining (Methuen 13-14B2 anterior, 13-14A3-4 posterior palate) with five blackish spots on the palate. The mouth pattern of the juveniles differed from the other indigobirds at Garoua, which have a yellow palate and lack the pale basal swellings at the gape (Payne 1982).

\section{Morphological description of Quail-finch Indigobirds}

Plumage colour of male Quail-finch Indigobirds in breeding plumage is dull glossy green (Fig. 7). The wings and tail are light brown. Mean wing-length is significantly larger than in Village Indigobirds in Nigeria and Cameroon and smaller than in green Jos Plateau Indigobirds $V$. maryae in Nigeria and in blue to green Black-faced Firefinch Indigobirds but is not different from the other west African indigobirds (Table 1). The under-wing coverts and the flank patch are white. The bill is white. The feet are purplish white, in contrast to Village Indigobirds with orange feet. The foot colour changes in birds held in captivity over an hour. It becomes darker purplish when birds are just captured or held in the hand, perhaps in response to changes in blood pressure or to stress. It is paler purplish when the birds are observed in the field, when birds are caged and at death.

No ovulating females were netted. Females were seen at a call-site of a colour-ringed Quail-finch Indigobird. They were brownish streaked above with dark grey, with a pale line above the eye and a dark eye stripe, the underparts were whitish and the feet were light purplish grey. Several were courted, and one mated on the call-site with the singing male Quail-finch Indigobird. She was observed at close range for several minutes. The females were not distinguishable from female indigobirds of most other species (Payne 1982).

The feet of juvenile indigobirds with a Quail-finch-like mouth pattern were purplish grey (13C2). The grey-brown plumage of the upperparts was indistinctly streaked, and the underparts were buffy and unstreaked as in juveniles of other species. They did not differ obviously in colour or pattern from juveniles of other west African indigobirds (Payne 1982).

\section{Distribution of Quail-finch Indigobirds}

Indigobirds with dull green breeding plumage and in association with Quail-finch occur at Garoua in Cameroon and Kiri in Nigeria. Both localities are on the flood plain of the Benue River and a tributary; Kiri is on the flood plain of the Gongola River $7 \mathrm{~km}$ above the Benue at Numan. At Garoua, six dull green males were recorded and collected in 1992, another was recorded, measured, ringed and released, and others (two in sparrowy plumage, one in dull green breeding plumage) were tape recorded. In addition, a dull green male was recorded and collected in 1979, and five were recorded but not captured in 1980. All had the songs and calls of Quail-finch. The indigobirds used the same trees as call-sites 
Table 1. Wing-length of male Vidua indigobirds in west Africa of known song mimicry

\begin{tabular}{|c|c|c|c|c|c|c|c|}
\hline \multirow[b]{2}{*}{ Vidua } & \multirow[b]{2}{*}{ Song mimicry } & \multirow[b]{2}{*}{ Origin* } & \multirow[b]{2}{*}{$n$} & \multicolumn{3}{|c|}{ Wing-length, mm } & \multirow[b]{2}{*}{ s.d. } \\
\hline & & & & Min & $\operatorname{Max}$ & Meant & \\
\hline V. chalybeata & 1.. senegala & $\mathrm{C}, \mathrm{N}$ & 15 & 59 & 64 & 62.07 & 1.75 \\
\hline 1. wilsoni & L. rufopicta & C. G, N.? & 13 & 61 & 66 & 63.00 & 1.47 \\
\hline I. larvaticola & L. larvata & $\mathrm{C}, \mathrm{N}$ & 16 & 64 & 69 & 66.69 & 1.54 \\
\hline V. camerunensis & L. nubricata & $\mathrm{C}$ & 14 & 63 & 66 & 64.86 & 0.95 \\
\hline V. maryae & L. rubricata & $\mathrm{N}$ & 4 & 66 & 69 & 67.75 & 1.50 \\
\hline V. camerunensis & L. rara & G.? & 4 & 62 & 65 & 63.75 & 1.50 \\
\hline I. nigeriae & O. atricollis & C & 8 & 63 & 66 & 64.25 & 1.04 \\
\hline V. raricola & A. subflava & $\mathrm{C}, \mathrm{S}$ & 19 & 61 & 67 & 64.05 & 1.68 \\
\hline I. camerunensis & C. monteiri & $\mathrm{C}$ & 8 & 63 & 67 & 65.00 & 1.31 \\
\hline
\end{tabular}

* $\mathrm{C}=$ Cameroon, $\mathrm{C}=$ Ghana, $\mathrm{N}=$ Nigeria, $\mathrm{S}=$ Sierra Leone, ?= imported captive.

$\dagger$ Anova, $F_{x, 3}=14.12, P<0.001$. Pairwise Scheffé comparisons of means are significant $(P<0.05)$ for chalybeata and larvaticola, maryae, nigeriae, and camenmensis mimics of $L$. rubricata. L. rara, and C. monteiri; for wilsoni and maryae, lanaticola and camerunensis mimics of $L$. rara and L. rubricata; for larvaticola and nigeriae, raricola, maryae, all camerunensis; and for maryae and raricola, nigeriae, and all camerunensis.

in all 3 years, and the population has persisted for at least 13 years on the flood plains south of Garoua.

Other specimens that appear to be Quail-finch Indigobirds are from Cameroon at Mabas and Touroua (MRAC field nos. 1.21250, 175.506) and Sidiri (Berlin Riggenbach no. 971. the same plumage colour as Berlin Riggenbach no. 1017 at Garoua), Sudan at Yei (Frankfurt, Mecklenburg no. 1/82) and The Gambia at Kuntaur (BMNH 1929.2.18.477-479480). Quail-finch occur in Sudan near Yei (Nikolaus 1987) and in The Gambia in open grassy areas near swamps and rice-growing areas (Gore 1981). Quail-finch Indigobirds may occur in other places with Quail-finch.

The holotype of the Quail-finch Indigobird and the Boyd Alexander expedition of 1904-1907

The type specimen of Hypochera nigeriae Boyd Alexander 1908 is BMNH 1911.12.23.3302, a male in dull green breeding plumage with pale wings. It closely resembles the Garoua birds. It was taken at Kiri on the Gongola River, Nigeria, on 22 July 1904. The BMNH register of specimens and Alexander's notebooks, both now at Tring, show that Quail-finch were found with it. There are five notebooks or diaries of Alexander with two from the 1904-1907 expedition. The itineraries of Alexander and his collector José Lopes in July 1904 were determined from the diaries, the BMNH register, B. Alexander (1907a) and J. Alexander (1977). Alexander's name appears as collector of Quail-finch in localities $600 \mathrm{~km}$ apart on nearly the same date (Lokoja on 17 and 25 July, Gongola River on 20 and 22 July), a discrepancy explained by the expedition leader writing his name as collector for the birds taken by Lopes as well as those he shot himself. Alexander and Lopes parted 1 July 1904, when Alexander went down the Benue River from Ibi to Lokoja, where he stayed until 28 July (Alexander 1907a, p. 186), then travelled inland to the north and east, not on the Gongola River.
He met Lopes again near the Yo River west of Lake Chad on 18-26 October 1904 (Alexander 1907a). Lopes took boats from Ibi upstream, arrived about 10 July at Lau and a week later at Numan, then travelled overland and up the Gongola River. About 15 species (the diary often did not include species names, and not all specimens were entered into BMNH) were taken at Kiri on the Gongola River on 22 and 23 July 1904. Quail-finch were taken at "Shale" (-Shillem. on the Gongola River below Kiri) on 20 July and on the Gongola River on 22 July, the date when the specimen of Hypochera nigeriae was taken at Kiri. Also taken at Kiri were Lavender Waxbill Estrilda caerulescens, but no other potential foster species were taken. The scarcity of supporting dairy notes in eastern Nigeria is explained by Alexander's writing of specimen labels and field notes days after the birds were collected (Alexander 1912, Alexander 1977) and the separation of Alexander and Lopes in July and August (Alexander 1907a). The dates and field numbers for specimens taken on the Gongola River as entered in the diary alternate irregularly with the dates and field numbers of birds taken on the Yo River. The historical records establish that the type specimen of the Quail-finch Indigobird occurred with Quailfinch.

\section{Goldbreast and Goldbreast Indigobirds}

Goldbreast are tiny, 6-7-g finches of grassy and marsh habitats with a wide range in Africa. They often breed in old covered nests of other species, but sometimes build their own nests, usually in tall grass (Chapin 1954, van Someren 1956, Hall \& Moreau 1970, Goodwin 1982). They feed on small grass seeds on the ground and on standing grass stems on which they perch. They are common in northern Cameroon in the areas of Banyo, Tibati, Meng and Ngaoundére, where we found them to be associated with glossy green Goldbreast Indigobirds. 
Amandava subflava, Goldbreast

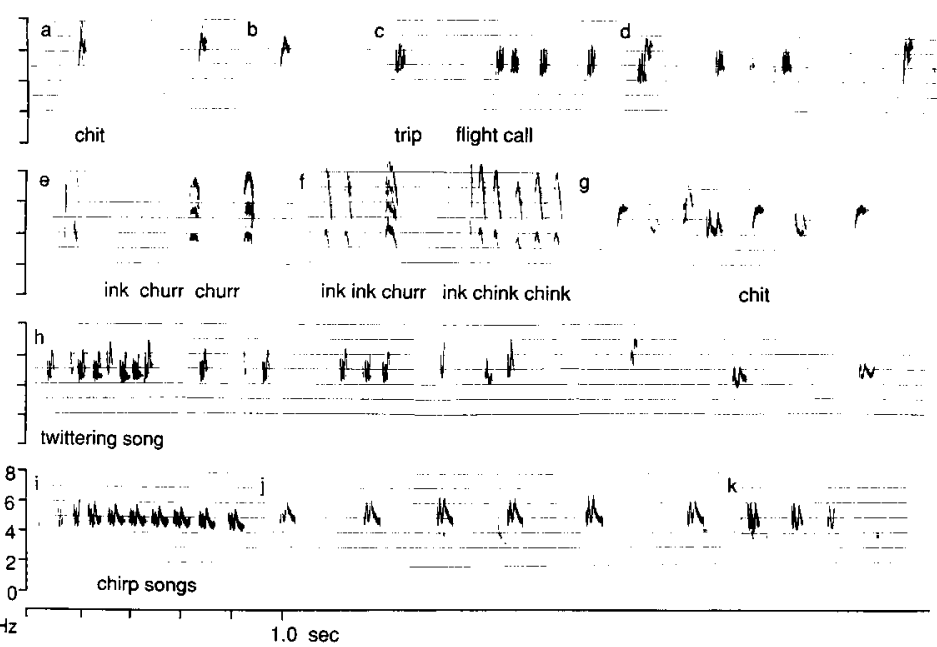

Figure 3. Songs and calls of Goldbreast. (a, b) Social contact call chit; (c) Trip flight call of male flying overhead toward its nest; (d) Trip and chit calls; (e, f) Alarm sequences "ink, ink, chur, chur" and "ink, chur, chink" by adult at nest with fledglings; (g) Tink and chirp notes; (h-k) Trip and chirp song sequences. (a, c, e, f) Recorded at Meng, Cameroon, 21 November 1992; (b) Nyakunde, Haut-Zaire, 26 March 1978 (Cornell 01530); (d) Moundou, Chad (recorded by J. Brunel, courtesy of C. Chappuis); (g) South Africa (Gilliard 1987); (h, i) Wild-caught captives from west Africa.

Vidua raricola, Goldbreast Indigobird

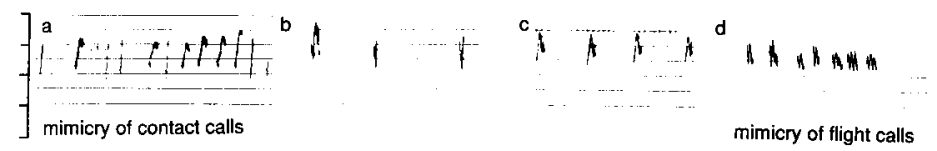

Figure 4. Mimicry songs of Goldbreast by the Goldbreast Indigobird (compare with Fig. 3). (a, b, c) Social calls chit; (d) Flight call trip; (d) Mimetic alarm calls chink; (e, f) Mimetic alarm sequences of chur, chink and ink notes, with chink repeated in $2 \mathrm{~s}$ and $3 \mathrm{~s}$; (g. h) Mimetic chirp song with a short element of the chit and a low cheup occurring at the beginning of the sequence; (i) "Chip clip chu" song series with some notes resembling trip; (j) Chit and chirp notes; (k) Mimetic song with intergrading chirps and chinks; (l) Weak twittering song of short chi and trip notes leading into ink and chinks, (m) mimicry of fledgling begging calls. (a, l) Recorded at Ngaoundére, Cameroon, 15 October 1992, RBP A130; (d) Ngaoundére, 10 November 1992, RBP A198; (b, e, g, i-k) Meng, 15 November 1992, not collected; 25 November 1992; (c, f, h, m) Meng, 15 November 1992, RBP A234.

\section{Songs and calls of Goldbreast}

The songs were described by Chapin (1954) as "a very weak twittering". Goodwin (1982) noted the male in breeding season has a "long series of remarkably loud and strident chirps. Often 3 or 4 high-pitched chirps are followed by one on a lower key and harsher in tone." The male sings "mainly in the early morning, starting before dawn ...", and we have heard this in aviary captives. Maclean (1985) described song as a "jumbled series of high-pitched notes, "chip chit cheet chink cheup chink, etc." 'Low-intensity song has been reported also from females and juveniles, and a soft version is given in courtship by the male (Colahan 1982). Colahan (1982) described the calls and song in words with some in audiospectrograms in Maclean (1985, p. 762), and we use these terms. A simple social contact call is a chit repeated
1-2 times per $\mathbf{s}$ as the bird moves about while feeding or in flight (Fig. 3a-c). The single note rises then falls in pitch and has a peak amplitude at $6-7 \mathrm{kHz}$. Flight calls trip are modulated and are given in flight (Fig. 3d). They also are given as flight intention calls and as an affiliative call when a pair or family group is separated and reunites and are like calls given in repeated series by perched birds (Fig. 3h). Alarm calls with a loud note chink form an inverted " $\mathrm{V}$ " on audiospectrograms. The calls often are given in a repeated series with harsh chur notes and short descending ink notes that are short versions of chink (Fig. $3 \mathrm{e}$ and f). Song is a series of calls that form " $M$ " shapes and repeat in series (Fig. $3 \mathbf{j}$ and $\mathrm{k}$ ) or intergrade with shorter trip notes (Fig. 3i). We refer to these calls as chirps. The begging calls of fledged young graph as intergrading "m:"s and "w"s (not shown).

Except for the alarm calls, which were loud and recorded 
at close range, the calls of Goldbreast have a simple harmonic structure with a single frequency band at any one time rather than a complex structure with harmonic bands as in Ouail-finch.

\section{Vocal mimicry by Goldbreast Indigobirds}

Songs of the adult male glossy green indigobirds with pale brown wings in Cameroon match the songs and calls of the Goldbreast (Fig. 4), as did glossy green indigobirds at Kabala, Sierra Leone (Payne 1982). We recorded all note and sequence variants recorded from Goldbreast (Fig. 3) from the indigobirds associated with them. In the indigobirds, the mimetic songs have a series of similar " $\mathrm{M}$ " notes that intergrade into a series of notes of inverted " $V$ " shape, with notes joining the " $M$ " and " $V$ " series having a nick in the apex of the " $V$ " (Fig. 4m). These mimic the distinctive begging calls of young Goldbreast and were recorded at Banyo, Tibati, Meng, Ngaoundére and Kabala. As in other species of indigobirds (Payne 1973, 1979, 1985b), the details of the mimetic songs and the nonmimetic songs (not shown here) are shared among neighbouring males. A near but not perfect match of mimicry songs of two males is shown in Figure $4 \mathrm{~g}$ and $\mathrm{h}$.

Nicolai (1968) reported indigobird song mimics of Blackbellied Firefinch and Black-faced Firefinch at the same locality at Ngaoundere in 1967. We did not find indigobirds with the songs of these firefinches, though the firefinches were there. Nicolai netted two male indigobirds (in Payne 1982) at Ngaoundére, one glossy green and one glossy blue in breeding plumage, but did not tape record them or other indigobirds. Both appear to be Goldbreast Indigobirds as they match the colours and gloss of our mimics of the Goldbreast at Ngaoundére (Fig. 7). Other estrildids at Ngaoundére include Bar-breasted Firefinch, Dark Firefinch Lagonosticta rubricata, Dybowski's Twinspot Eustichospiza dybowskii, Brown Twinspot, Quail-finch. Red-cheeked Cordon-Bleu, Lavender Waxbill, Common Waxbill Estrilda astrild, Black-crowned Waxbill Estrilda nonnula, Grey-headed Olive-back Nesocharis capistrata and Bronze Mannikin, all of which we tape recorded at Ngaoundére or elsewhere. None of the songs of the Goldbreast Indigobirds matched any of these other estrildid finches.

\section{Mouth patterns of young Goldbreast and indigobirds}

A juvenile Goldbreast netted at Banyo on 21 January 1979 had a pinkish-white palate with five black spots. It had a gape with a swollen pinkish base, two whitish to blue opalescent papillac on the upper mandible, and one blue papilla on the lower mandible. The base of the gape was swollen and grey. The areas between the swollen base of the gape and the papillae were black. Young that we bred in captivity had similar mouth patterns as nestlings. At hatching, the narrow gape swellings were white and not broken into the distinct papillae of the fledged young. The gape swellings developed black areas between them in the older nestlings. The central anterior spot had a pale centre. In front of this were two large black chevrons. Three black spots on the inner ridge also had white centres. The lower mouth lining had a row of four black spots. The mouth pattern was described also by Harrison (1962) and Colahan (1982).

Two juvenile indigobirds (UMMZ 202401, 202402), about 3 weeks fledged. were netted on 12 January 1979 near Ngaoundére at a site where we tape recorded and captured adult male Goldbreast Indigobirds with the songs of Goldbreast. They had two distinct gape papillae, one above and one below, both with black at the base, and the upper papilla was posterior to the lower one. The papillae were whitish to pale blue (21A3), the area between was dark blue (21E6) to black, the gape swelling was pale grey and the palate was pinkish (14A2) with five blackish spots. The mouth patterns resembled those of Goldbreast and differed from the other indigobirds seen at Ngaoundére. Bar-breasted Firefinch Indigobirds $V$. wilsoni lack distinct gape papillae but have a white swelling extending across the upper and lower bases of the bill, as in its foster the Bar-breasted Firefinch (Payne 1982). Two juvenile indigobirds, one in postjuvenal moult, netted at Banyo on 21 January 1979 (UMMZ 202398, 202399) a few metres from a singing male Goldbreast Indigobird, had the distinct gape swelling with two whitish papillac separated by black, as in the younger juveniles at Ngaoundere.

\section{Brood parasitism of Goldbreast}

On 25 November 1992 at Meng, L.L.P. observed a juvenile indigobird attended by two Goldbreast, one an adult male and the other a female or juvenile. The indigobird had papillae on the gape. It flew across a marsh and called (not tape recorded). This is the only record we have of a young indigobird attended by a Goldbreast.

\section{Morphological description of Goldbreast Indigobird}

Plumage colour of adult male Goldbreast Indigobirds in breeding plumage is bright glossy green to greenish blue (Fig. 7). The wings and tail are light brown. Mean winglength is significantly larger than in Village Indigobirds in Nigeria and Cameroon and smaller than in green Jos Plateau Indigobirds $V$. maryae in Nigeria and in the blue to green Black-faced Firefinch Indigobird but is not different from the other west African indigobirds (Table 1). The under-wing coverts and the flank patch are white. The bill is white. The feet of live males are purplish white. The feet become darker purplish when birds are just captured or are held in the hand. The feet are paler purplish when the birds are observed in the field and after death.

Five breeding female indigobirds were netted at the callsite of a singing male as he mimicked songs of Goldbreast. One female (hard egg in oviduct) was netted at a call-site with a male at Kabala, Sierra Leone, in 1973; two ovulating females were captured at a call-site of a male at Ngaoundére in 1980 and two ovulating females were captured at the site of a male at Meng in 1992. All were brownish above with dark grey streaks, they had a dark eye stripe, the breast was grey and the belly was whitish. Wing-length $(61-65 \mathrm{~mm})$ 
averaged $63.0 \pm 1.41$ s.d. $\mathrm{mm}$. The feet when alive were pinkish grey to purplish grey. The females were similar in appearance to females of other species of indigobirds in west Africa (Payne 1982).

The feet of juvenile indigobirds with a mouth pattern like that of Goldbreast were light purplish grey (13C2). The greybrown plumage of the upperparts was indistinctly streaked and had a pale line above the eye and a darker line through the eye, and the underparts were buffy as in the other species. They did not differ in colour or pattern from juveniles of other west African indigobirds.

\section{Distribution of Goldbreast Indigobirds}

In Cameroon, nine male indigobirds in glossy green plumage were tape recorded with mimetic songs of Goldbreast and then were collected in 1992. Eight other males were recorded and not netted: two were in sparrowy plumage, one was glossy blue and the others were glossy green. In 1979 , a male was recorded and collected and five others (one sparrowy) were tape recorded with these songs at Tibati and Banyo. In 1980, seven males were tape recorded and collected at Ngaoundére and Banyo and 11 others were recorded there and at Tibati (Payne 1982, Payne \& Groschupf 1984). Glossy green indigobirds were collected at Tibati by Bates (Bannerman \& Bates 1924, specimens at Tibati and other localities are listed in Payne 1982). The Goldbreast Indigobird occurs also at Kabala and Musaia in northern Sierra Leone (Payne 1982). Goldbreast are known in northern Sierra Leone at Kabala (R.B. Payne \& L.L. Payne, pers. obs.), Kamaron (Serle 1949), Kilimi (Harding \& Harding 1982), Loma Mountains, Bumban, Gbengbe Hills and Kamakwie (BMNH, G.D. Field, pers. comm.). We observed Goldbreast in all localities in Cameroon where we found Goldbreast Indigobirds. The indigobirds may be elsewhere where Goldbreast occur.

Specimens identified by plumage as Goldbreast Indigobirds occur also in west Africa from Cameroon at Fumban 50 miles southwest at 3000 feet. Bambalong at 3500 feet (BMNH 1926.8.8.539, 1966.16.3997) and Abong Mbang (FMNH 274896, 274897), Nigeria at Enugu (BMNH 1966.16.3996) and Kogum (BMNH 1928.7.20.248), Ghana at Yegi (BMNH 1927.7.209.154) and Sierra Leone at Makeni and Bintimani Peak at 1800 feet (BMNH 1946.40.78, 1951.50.35). In central Africa, specimens are known from Zaire at Faradje (AMNH 161948) and Sudan at Kulme, Darfur (BMNH 1922.12.8.1939) and Nimule (Berlin 399.66.710). Goldbreast are known at some of these localities and near the others.

\section{Brown Twinspots and Brown Twinspot Indigobirds}

Brown Twinspots live in high grass in the savannas of central Africa as far west as northern Cameroon and eastern Nigeria (Chapin 1954, Hall \& Moreau 1970, Louette 1981, Elgood 1982, Goodwin 1982). They nest on the ground and in trees. They often use an old nest of other species (Chapin 1954), though they may build their own nest (Mackworth-Praed \&
Grant 1973, Neff 1975). They feed on the ground, often in cultivated manioc fields, on termites and small grass seeds (Bates 1930, Chapin 1954, R.B. Payne \& L.L. Payne, pers. obs.). At Meng and Tibati in 1992, we tape recorded a population of indigobirds with blue male breeding plumage that were associated by songs and local habitats with the Brown Twinspot. Their species status is uncertain. We refer to them as Cameroon Indigobirds $V$. camerunensis, though as similar blue indigobirds are associated with other estrildid finches, the name may apply to other populations as well.

\section{Songs and calls of Brown Twinspots}

The contact call is a repeated vay, vay, vay given in series from a distance to a social partner. The alarm call is described as a hard-sounding tek. Chapin (1954) and Mackworth-Praed \& Grant (1973) described the twinspot as giving "a sharp petulant little call and a good deal of twittering". Song of the male has a series of rolling and piping notes (Neff 1975, Goodwin 1982).

At Banyo, the twinspots gave a series of whistles that rose sharply to $3-4 \mathrm{kHz}$ then descended gradually to $2-3 \mathrm{kHz}$ with a sharp drop on the end (Fig. 5). These appear to be the vay, vay, vay contact call, and their whining quality may indicate the "petulant little call". Another call type was a short note forming an acute inverted " $\mathrm{V}$ " (Fig. 5). Another was a harsh, short tek, given in series by an adult at Banyo and by another at Ngaoundére, each when we held it in a net bag, and was an alarm or disturbance call.

Brown Twinspot song is given in male courtship display (Neff 1975). Chappuis recorded song and the twinspot responded with longer songs after playback (Fig. 5), so song may by used in aggression as well. Several songs had crackling or swizzling sounds with notes rising in pitch (Fig. 5), perhaps the "Euplectes-like crackling" of Harrison \& Dormer (1962). R.B.P. recorded a similar song of a male at Banyo. Song includes a series of notes sirnilar in form to the contact notes vay, with a wide range of length and varying within a series. As in other estrildids (Immelmann 1968), the song may be derived from contact calls. Song also includes a series of sharp tek notes and inverted " $V$ " notes (Fig. 5), lower in pitch than the chink of Goldbreast. Song also has whistled notes that are low-pitched, rising, and falling in an inverted " $U$ "; these vary in form within a series from " $V$ "s to prolonged notes with $2-3 \mathrm{kHz}$ as the lowest frequency band and sometimes with a louder harmonic at 4-6 kHz. These are our peu notes (Fig. 5). The phrasing of 3 or 4 peus and their transition in form within a series phrase may account for the "rolling" effect described by Neff (1975).

\section{Vocal mimicry by the indigobirds}

Blue indigobirds at Tibati and Meng gave a series of mimetic vay, vay, vay, tek, " $V$ " calls and peu in their songs (Fig. 6). These closely resembled the calls of the Brown Twinspot (Fig. 5). Songs were stereotyped with the sequence of elements shared among male indigobirds (Fig. 6e and g, 6f and h), though the numbers of each element varied both within 


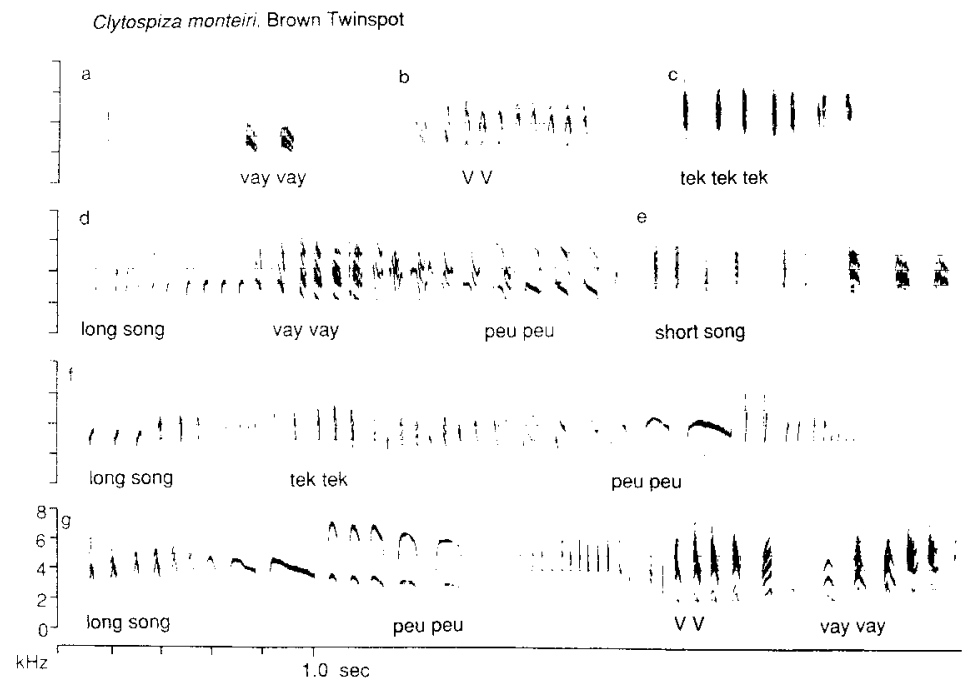

Vidua sp. Brown Twinspot Indigabird

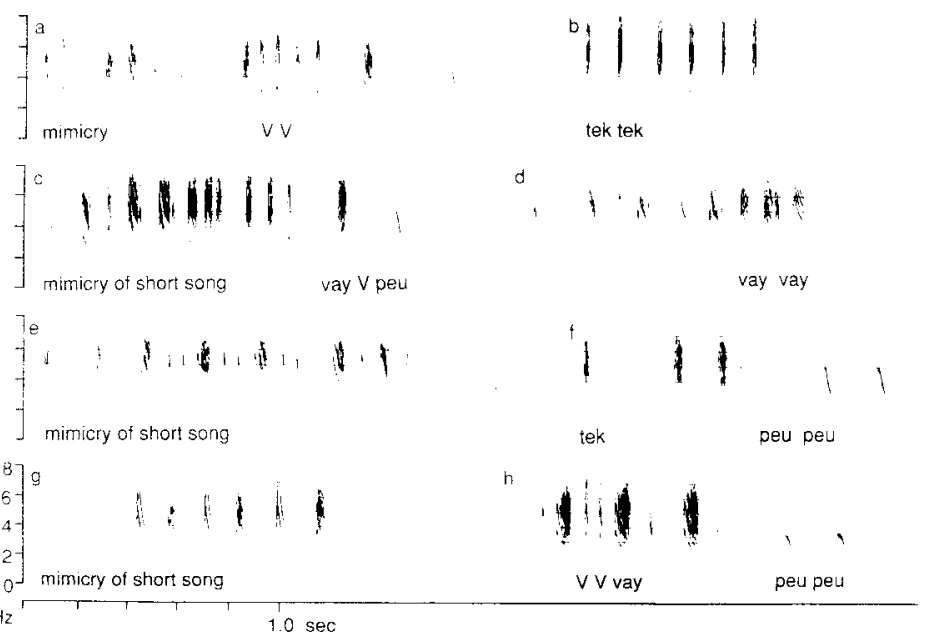

Figure 5. Songs and calls of Brown Twinspot. (a) Contact calls vay. vay; (b) Calls of inverted "V"; (c) Alarm calls tek. tek; (d, f, g) Long songs with elements of vay. "V" and peu; (e) Short song (it was followed by tek, tek). (a, b, d) Recorded at Banyo, Cameroon. 9 November 1980; (c) Meng, 23 November 1992; (eg) Melong, Cameroon, recorded 31 December 1975 by C. Chappuis. a male and among males (Fig. 6a, c, e, f and h). Some mimetic songs had notes intermediate in form between the calls of the twinspots, such as peu with a descending part like that in the vay notes (Fig. 6 f and $h$ ). We did not record indigobirds with the complex long songs of twinspots, though we did record stereotyped sequences of the calls, and these occur in the twinspot songs (Fig. 5). Twinspots may give long song infrequently and indigobirds may have few opportunities to hear it or the recordings of the indigobirds' song repertoires may be incomplete.

None of the 13 males recorded with calls and song of Brown Twinspot had a mixed repertoire with other calls or songs of the other estrildid finches at Tibati and Meng, including Black-bellied Firefinch, Bar-breasted Firefinch, Dark Firefinch, Dybowski's Twinspot, Goldbreast, Grey-headed Olive-back and Black-bellied Seed-cracker Pirenestes ostrinus. Other estrildids were mimicked by other indigobirds-
Dark Firefinches were mimicked by blue indigobirds (here called Cameroon Indigobirds) and Bar-breasted Firefinches were mimicked by purplish Bar-breasted Firefinch Indigobirds. Black-bellied Firefinches were common there and at Banyo, but we did not find indigobirds with their songs, though at Damongo and Mole National Park in Ghana, blue indigobirds mimic this firefinch (Payne 1982).

\section{Mouth patterns of the young twinspots and indigobirds}

Fledgling Brown Twinspots captured at Ngaoundére, Meng and Tibati had enlarged yellow gape swellings at the base of the upper and lower mandibles. The swelling on the lower mandible had an anterioventral spot of orange. The palate was bright yellow with a ring of five black spots. A similar pattern was described by Chapin (1954).

We captured a juvenile indigobird (UMMZ 232498) at a 
call-site at Tibati where over 2 weeks we recorded three male song mimics of the Brown Twinspot as one was replaced by the next. The mouth pattern of the indigobird was pink with a distinct purplish red gape and two pale blue papillae at the side. It resembled the mouth of young Blackbellied Firefinch (Chapin 1954, Payne 1982) rather than the young twinspot.

\section{Morphological description}

Adult male indigobirds with the songs of Brown Twinspot at Tibati and Meng were glossy blue in breeding plumage with brown wings and tail and pale purplish feet. They did not differ in colour and size from blue male indigobirds with the songs of Dark Firefinch at Wakwa, Tibati, Meng or Banyo in Cameroon, or in colour from males observed at Kabala, Sierra Leone. They did not differ from males with songs of Black-bellied Firefinch at Damongo and Mole National Park, Ghana, or from song mimics of this firefinch that we taped in captivity (Payne 1976, 1982; Fig. 7. Table 1). They averaged larger than Village Indigobirds and Bar-breasted Firefinch Indigobirds and smaller than Black-faced Firefinch Indigobirds and Jos Plateau Indigobirds of Nigeria (Table 1). The under-wing coverts and the flank patch were white. The bill was white, and the feet were purplish white. As in other pale-footed forms, the feet became darker purplish when the birds were held in the hand for a few minutes, then within an hour after death they were paler purplish as in birds in the field.

Two ovulating female indigobirds with a yolk in the oviduct (UMMZ 232496, 232497) were netted at the call-sites of the blue song mimics of twinspots at Tibati in 1992. The females were streaked above, their feet were light purplish grey and their wings were 61 and $62 \mathrm{~mm}$. They were not distinguishable from the female Quail-finch Indigobird, Goldbreast Indigobird, Black-faced Firefinch Indigobird or Bar-breasted Firefinch Indigobirds (Payne 1973, 1982). The captured juvenile resembled the juveniles of other kinds of indigobirds in plumage and in its pale purplish foot colour.

\section{Distribution}

Indigobirds that are associated by song with Brown Twinspot are known only from Tibati and Meng in Cameroon. They may occur elsewhere in the range of the twinspot. Because the adult males are similar morphologically to blue males that mimic other estrildid species, and the females are similar to these other indigobirds, they are not distinguishable in museum specimens.

\section{DISCUSSION}

\section{Species criteria}

To recognize a distinct population as a species, we suggest that it is necessary to have a distinct genetic criterion, though this may not be sufficient. In the indigobirds, we require either a morphological difference or a distinct molecular

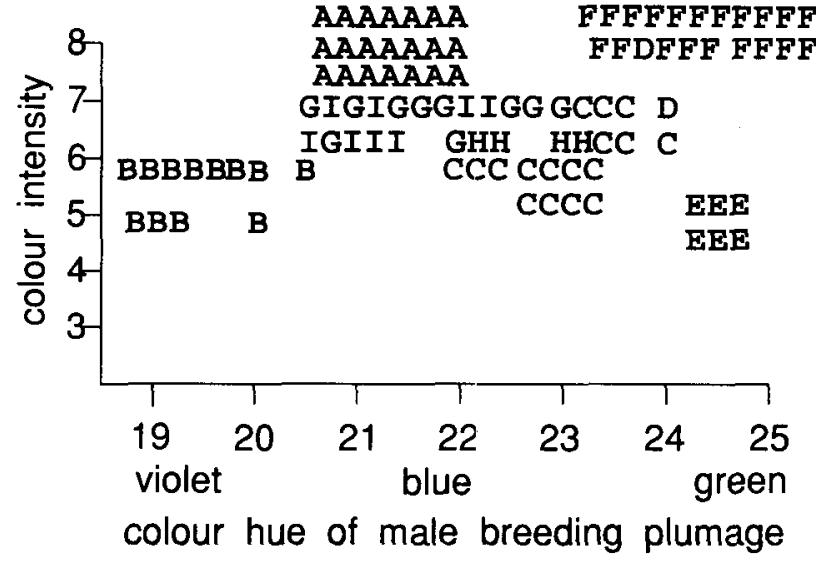

Figure 7. Colour of breeding plumage in male indigobirds of known song mimicry for which songs were tape recorded. All were recorded in west Africa except for three imported captives. Hues and intensities are page and row of a colour standard (Kornerup \& Wanscher 1967). (A) Vidua chalybeat a neumanni; (B) V. wilsoni; (C) V. larvaticola; (D) V. maryae; (E) V. nigeriae; (F) V. raricola; (G) mimics of Dark Firefinch; (H) mimics of Black-bellied Firefinch; (I) mimics of Brown Twinspot. Note the distinctiveness of $\mathrm{A}, \mathrm{B}, \mathrm{D}, \mathrm{E}$ and $\mathrm{F}$ and overlap of the other forms in plumage colour.

genetic trait. For this reason it was recommended that a species is not recognized on the basis of song alone (Payne 1976), though most song-mimicry populations now are known to differ in mouth markings of the young, so are distinct genetically (Payne 1982). We do not recognize a species if song is the only distinct trait because the indigobirds can learn songs from alternative foster species as well as from their usual foster and from each other (Payne 1973, 1985b, Payne et al. 1992, 1993).

By this reasoning, we recognize Vidua nigeriae and $V$. raricola as species, as the male breeding plumages and the mouth patterns of the young are known to be distinct. However, we are uncertain about the indigobirds that mimic the Brown Twinspot because no morphological differences are known between those birds and the blue-plumaged song mimics of some other kinds of indigobirds, and no molecular genetic comparisons have been completed. The indigobirds associated with Brown Twinspots may be a distinct species with a mouth pattern as in the young twinspots. On the other hand, they may be a population that has recently switched from one foster to another (perhaps indigobirds that were associated with the Black-bellied Firefinch). This is suggested because the juvenile captured at the site of a male indigobird with the songs of a Brown Twinspot may have been attracted to the mimetic songs of its own foster species, yet it had the mouth pattern of the firefinch. Juvenile Village Indigobirds and Purple Indigobirds $V$. purpurascens at Lochinvar National Park, Zambia, were seen repeatedly to visit the call-sites of males that mimicked their foster species (R.B. Payne, unpubl. obs.). The similarity of male breeding plumage and foot colour in the mimics of Brown Twinspot at Tibati, mimics of Dark Firefinch in Cameroon 
and Sierra Leone, and mimics of Black-bellied Firefinch in Ghana (mimics of this firefinch were not seen at Tibati but may have been overlooked) suggests a common origin. Plumage colour and size of these three kinds of song mimics are similar to each other. The indigobird mimics of the Brown Twinspot may not have undergone detectable genetic divergence such that they can be recognized as a distinct species. Additional studies are needed to determine their species status.

\section{Species names}

Vidua raricola is associated with the Goldbreast, rather than with the Black-bellied Firefinch as implied by its species name. The original description of $V$. raricola (Payne 1982 , pp. 24-25) included audiospectrograms of birds that mimicked these two species, but the type specimen when alive had the songs of Goldbreast, and no male had a mixed song repertoire.

As in Payne (1982), the name Vidua camerunensis cannot be applied with certainty to any one kind of indigobird with blue plumage, as several kinds of west African pale-winged indigobirds are blue, and the songs and foster species association of the type specimen are not determinable. It is possible that the name camerunensis will apply specifically to the blue indigobirds that are associated with Dark Firefinch, with Black-bellied Firefinch, with Brown Twinspot. or with another species of estrildid. No mouth marking or colour differences have been determined for young of these indigobirds associated with these foster species. The species name $V$. lanaticola is used, however, for the blue birds associated in song and in the distinctive mimicry of the mouth pattern and colours with their foster species, the Black-faced Firefinch (Payne 1982).

The dull green holotype of $V$. nigeriae is identifiable as it matches the dull green plumage of birds that mimic Quailfinch and not the larger, bright green birds with the songs of Dark Firefinch on the Jos Plateau in Nigeria, the larger, green or blue-green birds with the songs of Black-faced Firefinch or the bright green birds with the songs of Goldbreast. Because the holotype of $V$. nigeriae resembles in its dull green breeding plumage the song mimics of Quail-finch at Garoua and differs from the other indigobirds. nigeriae is no longer considered a nomen dubium as in Payne (1982).

\section{Evolutionary associations of indigobirds and their estrildid foster species}

The indigobird species are more similar in morphology than are their estrildid foster species. In the presence of intense sexual selection in Vidua (Payne \& Payne 1977, Payne 1984), one would expect a greater divergence of visual traits than in the monogamous foster species. Yet within a species complex the viduines appear much alike. A comparison of their morphology suggests that the differences among the brood parasite species are small due to recent colonization of their foster species. In contrast to the indigobirds, their foster species are a diverse group and not a single evolutionary lineage distinct from the species parasitized by other viduine species groups (Wolters 1987), such as Violet-cheeked Waxbill Granatina granatina and Purple Grenadier G. ianthinogaster, which are parasitized by Straw-tailed Whydah Vidua fischeri and Shaft-tailed Whydah V. regia (Nicolai 1964, 1969. Skead 1975).

In southern Africa, female $V$. chalybeata are distinctive with their red bill and feet and are distinguished from the other indigobirds with whitish bills. In the areas where $V$. codringtoni live together with $V$. chalybeata and either $V . f u-$ nerea or $V$. purpurascens, the female $V$. codringtoni are distinctive in their white bill, orange feet and grey breast plumage. Where two or more kinds of indigobirds occur together and their females differ in these areas, we observed the constancy of association of the females with the males at their mating sites. In nearly all observations, the females were the same form as the male. At Lochinvar National Park, Zambia, where $V$. chalybeata occurs with $V$. purpurascens. matings were observed in 1973 and 1976 mainly at the callsites of singing $V$. chalybeata. All 51 matings recorded were of $V$. chalybeata with $V$. chalybeata and $V$. purpurascens with $V$. purpurascens, and their assortative mating was highly nonrandom (Payne 1973, 1980, Payne \& Payne 1977, Payne et al. 1993). The mating and the consistent association of male song behaviour with male morphology indicate that the indigobirds do not interbreed to a great extent and they behave as distinct species.

Although song mimicry and assortative mating are usual, a few males minic the wrong or alternate species (Payne 1973, Payne et al. 1992, 1993). We do not know their histories but suggest that they learned their songs when reared by an alternate foster species. Observations of males singing an alternate song suggest that a female occasionally may lay in the nest of an alternate foster species, where her young are reared successfully even though the mouth markings of the indigobird do not match this foster species. In another estrildid finch, parents will rear the young of others with odd mouth patterns if they have good feeding conditions, but selectively feed their own young if they have marginal feeding conditions (Reed \& Freeman 1991). The behavioural success of the indigobirds with an alternate song in holding a song site and attracting females (Payne 1973, 1980) indicates a potential for the colonization of a new foster species. If females are reared by the alternate species, they may imprint on the new foster and then lay their eggs in its nests. Successful rare switches in foster species may have preceded the genetic differentiation of Vidua populations and species (Payne 1973, Payne et al. 1993). The diversity of foster species in four genera of estrildids as well as in the firefinches Lagonosticta, together with field evidence of occasional switches from one foster species to another as perhaps in the indigobirds that mimic songs of Brown Twinspot, suggests an evolutionary association of each species of indigobird with its foster species through the colonization of new foster species rather than through cospeciation with their 
old foster species. The behavioural observations are consistent with estimates of molecular genetic divergence which show that the Vidua are more similar to each other than are their foster species (Klein et al. 1993).

For permits to do research and collect and export specimens, we thank the Government of the Republic of Cameroon, in particular the Institute for Zoological Research (IRZ). R. J. Breitwisch, K. D. Groschupf and N. K. Klein helped in the field. G. D. Field commented on localities in Sierra Leone. Several museums allowed examination of specimens (American Museum of Natural History [AMNH], Berlin Museum, Field Museum of Natural History [FMNH], Senckenberg Institute and Museum at Frankfurt, U.S. National Museum, Natural History Museum [BMNH] at Tring, Museum of Central Africa [MRAC] at Tervuren, Muséum National d'Histoire Naturelle at Paris and the Museum Alexander Koenig). M. Walters and A. Moore provided copies of the BMNH specimen register and Boyd Alexander's diaries and other historical documents, and $M$. Walters made the originals available at Tring. C. Chappuis, F. Dowsett-Lemaire, R. Stjernstedt (Stjernstedt 1993) and the Cornell Laboratory of Ornithology sent copies of tape recordings. Copies of our tape recordings have been deposited with $\mathrm{C}$. Chappuis and the British Library of Wildlife Sounds (BLOWS). The original recordings and specimens are in the University of Michigan Museum of Zoology (UMMZ). We thank N. K. Klein and C. S. Parr for comments on the manuscript. Field work was supported by grants from the National Science Foundation and the National Geographic Society.

\section{REFERENCES}

Alexander, B. 1907a. From the Niger to the Nile, Vols 1 and 2. London: Edward Arnold.

Alexander, B. $1907 \mathrm{~b}$. From the Niger, by Lake Chad, to the Nile. Geogr. J., Lond. 30: 119-152, map.

Alexander, H. (ed.). 1912. Boyd Alexander's Last Journey. London: Edward Arnold.

Alexander, J. 1977. Whom the Gods Love. London: Heinemann.

Bannerman, D.A. 1949. The Birds of Tropical West Africa, Vol. 7. Edinburgh: Oliver \& Boyd.

Bannerman, D.A. \& Bates, G.L. 1924. On the birds collected in north-western and northern Cameroon and parts of northern $\mathrm{Ni}$ geria. Part 3. Annotated list of species. Ibis ser. 11, 6: 519-549.

Bates, G.L. 1930. Handbook of the Birds of West Africa. London: John Bale, Sons \& Danielsson.

Chapin. J.P. 1954. The birds of the Belgian Congo, part 4. Bull. Amer. Mus. Nat. Hist. 75B.

Colahan, B.D. 1982. The biology of the Orangebreasted Waxbill. Ostrich 53: 1-30.

Elgood, J.H. 1982. The Birds of Nigeria. BOU Check-list No. 4. London: British Ornithologists' Union.

Gilliard, L. 1987. Southern African Bird Calls, Part 3. Johannesburg: Gilliard Bird Cassettes.

Goodwin, D. 1982. Estrildid Finches of the World. London: British Museum (Nat. Hist.).

Gore. M.E.J. 1981. Birds of The Gambia. BOU Check-list No. 3. London: British Ornithologists' Union.

Güttinger, H.R. \& Nicolai, J. 1975. Struktur und Funktion der Rufe bei Prachtfinken (Estrildidae). Z. Tierpsychol. 33: 319-334

Hall, B.P. \& Moreau, R.E. 1970. An Atlas of Speciation in African Passerine Birds. London: British Museum (Nat. Hist.).
Harding, D.P. \& Harding, R.S.O. 1982. A preliminary checklist of birds in the Kilimi area of northwest Sierra Leone. Malimbus 4: 64-68.

Harrison, C.J.O. 1962. The mouth-markings of the nestlings of Amandava subflava (Vieill.). Bull. Br. Ornithol. Club 82: 173-174.

Harrison, C.J.O. \& Dormer, B.P. 1962. Notes on the display and behaviour of Peter's Twinspot and the Brown Twinspot. Avicult. Mag. 68: 139-143.

Immelmann, K. 1968. Zur biologischen Bedeutung des Estrildidengesanges. J. Orn. 109: 284-299.

Immelmann, K., Steinbacher, J. \& Wolters, H.E. 1965. Prachtfinken, 2nd ed., Vol. 1, Astrilde. Aachen: Verlag Hans Limberg.

Klein, N.K., Payne, R.B. \& Nhlane. M.E.D. 1993. A molecular genetic perspective on speciation in the brood parasitic Vidua finches. Proc. Pan-Afr. Orn. Congr. 8: 29-39.

Kornerup, A. \& Wanscher, J.H. 1967. Methuen Handbook of Colour, 2nd ed. London: Methuen.

Kunkel, P. 1966. Bemerkung zu einigen Verhaltensweisen des Rebhuhnastrilds, Ortygospiza atricollis atricollis (Vieillot). Z. Tierpsychol. 23: 136-140.

Louette, M. 1981. The Birds of Cameroon. An annotated checklist. Paleis der Academiën, Brussels: Verhandelingen van de Koninklijke Academie voor Wetenschappen. Letteren en Schone Kunsten van België 43, No. 163.

Mackworth-Praed, C.W. \& Grant, C.H.B. 1973. Birds of West Central and Western Africa, Vol. 2, African Handbook of Birds, Series 3. London: Longman.

Maclean, G.L. 1985. Roberts' Birds of Southern Africa. Cape Town: John Voelcker Bird Book Fund.

Neff, R. 1975. Der Braune Tropfenastrild. Gefiederte Welt 101: 181-184.

Nicolai, J. 1964. Der Brutparasitismus der Viduinae als ethologisches Problem. Z. Tierpsychol. 21: 129-204.

Nicolai, J. 1967. Rassen- und Artbildung in der Viduinengattung Hypochera. 1. Hypochera purpurascens Reichenow-Brutparasit beim Dunkelroten Amaranten Lagonosticta rubricata (Lichtenstein). J. Orn. 108: 309-319.

Nicolai, J. 1968. Wirtsvogel-Beziehungen der Hypochera Formen camerunensis und nigeriae. Naturwissenschaften 53: 654.

Nicolai, J. 1969. Beobachtungen an Paradieswitwen (Steganura paradisaea L., Steganura obtusa Chapin) und der Strohwitwe (Tetraenura fischeri Reichenow) in Ostafrika. J. Orn. 110: 421-447.

Nicolai, J. 1973. Das Lernprogramm in der Gesangsausbildung der Strohwitwe Tetraenura fischeri Reichenow. Z. Tierpsychol. 32: 113138.

Nicolai, J. 1977. Der Rotmaskenastrild (Pytilia hypogrammica) als Wirt der Togo-Paradieswitwe (Steganura togoensis). J. Orn. 118: 175-188.

Nikolaus, G. 1987. Distributional atlas of Sudan's birds with notes on habitat and status. Bonner Zooll. Monogr. 25.

Nuttall, R.J. 1992. Breeding biology and behaviour of the Quail Finch Ortygospiza atricollis. Ostrich 63: 110-117.

Payne, R.B. 1968. Mimicry and relationships in the indigobirds or combassous of Nigeria. Niger. Orn. Soc. Bull. 5: 57-60.

Payne, R.B. 1973. Behavior, mimetic songs and song dialects, and relationships of the parasitic indigobirds (Vidua) of Africa. Orn. Monogr. 11.

Payne, R.B. 1976. Song mimicry and species relationships among the west African pale-winged indigobirds. Auk 93: 25-38.

Payne, R.B. 1977. Clutch size, egg size, and the consequences of single vs. multiple parasitism in parasitic finches. Ecology 58: 500513.

Payne, R.B. 1979. Song structure, behaviour, and sequence of 
song types in a population of Village Indigobirds, Vidua chalybeata. Anim. Behav. 27: 997-1013.

Payne, R.B. 1980. Behavior and songs in hybrid parasitic finches. Auk 97: 118-134.

Payne, R.B. 1982. Species limits in the indigobirds (Ploceidae, Vidua) of west Africa: Mouth mimicry, song mimicry, and description of new species. Misc. Publ. Univ. Mich. Mus. Zool. 162.

Payne, R.B. 1984. Sexual selection, lek and arena behavior, and sexual size dimorphism in birds. Orn. Monogr. 33.

Payne, R.B. 1985a. The species of parasitic finches in west Africa. Malimbus 7: 103-113.

Payne, R.B. 1985b. Behavioral continuity and change in local song populations of Village Indigobirds Vidua chalybeata. Z. Tierpsychol. 70: $1-44$.

Payne, R.B. \& Groschupf, K.D. 1984. Sexual selection and interspecific competition: A field experiment on territorial behavior of nonparental finches (Vidua spp.). Auk 101: 140-145.

Payne, R.B. \& Payne, K. 1977. Social organization and mating success in local song populations of Village Indigobirds, Vidua chalybeata. Z. Tierpsychol. 45: 113-173.

Paync, R.B., Payne, L.L. \& Nhlane, M.E.D. 1992. Song mimicry and species status of the Green Widowfinch Vidua codringtoni. Ostrich 63: 86-97.

Payne, R.B., Payne, L.L., Nhlane, M.E.D. \& Hustler, K. 1993. Spe- cies status and distribution of the parasitic indigo-birds Vidua in east and central Africa. Proc. Pan.-Afr. Orn. Congr. 8: 40-52.

Reed, H.J. \& Freeman, N.H. 1991. Does an absence of gape markings affect survival of leucistic young in the Zebra Finch? Bird Behaviour 9: 58-63.

Schifter, H. 1963. Erfolgreiche Aufzucht von fünf Wachtelastrilden. Gefiederte Welt 89: 16-18.

Serle, W. 1938. Observations on the breeding habits of Nigerian estrildine weaver-birds. Oologists' Record 18: 40-45, 60-63.

Serle, W. 1949. Birds of Sicrra Leone (Part IV). Ostrich 20: 114126.

Skead, D.M. 1975. Ecological studies of four estrildines in the central Transvaal. Ostrich Suppl. 11: 1-55.

Stjernstedt, R. 1993. Birdsong of Zambia, Part III, Warblers to buntings (tape cassette). Lusaka: R. Stjernstedt.

Traylor, M.A. 1963. Revision of the Quail Finch Ortygospiza atricollis. Bull. Br. Ornithol. Club 83: 141-146.

van Someren, V.G.L. 1956. Days with birds. Studies of habits of some east African species. Fieldiana, Zool. 38.

Wolters, H.E. 1987. Zur Stammesgeschichter der afrikanischen Prachtfinken. Trochilus 8: 37-76.

Submitted 26 July 1993: accepted 9 September 1993 